\title{
Extreme variation in the prevalence of inherited male-killing microorganisms between three populations of Harmonia axyridis (Coleoptera: Coccinellidae)
}

\author{
TAMSIN M. O. MAJ ERUS*, MICHAEL E. N. MAJ ERUS, BRIGITTE KNOWLES, \\ J OY WHEELER, DOMINIQUE BERTRAND, VICTOR N. KUZNETZOV $\dagger$, HIDEKI UENO \\ \& GREGORY D. D. HURST \\ Department of Genetics, Downing Street, Cambridge CB2 3EH, U.K., †Institute of Biology and Soil Science, Far East \\ Branch Russian Academy of Sciences, Vladivostok, 690023, Russia and łLaboratory of Biology, Faculty of Education, \\ Niigata University, 8050, Ikarashi-Ni-No-Cho, Niigata 950-21, J apan
}

Females from three populations of Harmonia axyridis (Pallas) were assayed for two phenotypical indicators of the presence of male-killing endosymbionts: low egg hatch-rates and strongly female-biased progenic sex ratios. Samples from Sapporo City, Japan, and the Altai Mountains, Mongolia, but not from Novosibirsk, Russia, were found to contain some females displaying both of these traits. Furthermore, there was a profound difference in the prevalence of infection between the Japanese and Mongolian populations. The proportion of females infected from the Japanese sample was approximately 0.49 , whereas that from Altai was only 0.02. The trait was inherited by more than $99 \%$ of the progeny of infected females. The trait was inherited maternally with the same high efficiency over five generations. Treatment with antibiotics produced a small increase in the production of males from the male-killing lines, suggesting that the male-killer is bacterial in nature. Causes of variation in prevalence are discussed, and the consequences of high levels of infection with an efficiently transmitted malekilling microorganism on host population demography are considered.

Keywords: Coccinellidae, cytoplasmic microorganisms, Harmonia axyridis, male-killing, maternal inheritance, sex ratio.

\section{Introduction}

Maternally inherited female-biased sex ratio traits have been found in a number of species of coccinellid (Adalia bipunctata - Lus, 1947; Hurst et al., 1992; Harmonia axyridis - Matsuka et al., 1975; Hu, 1979; Gotoh \& Niijima, 1986; Menochilius sexmaculatus - Niijima \& Nakajima, 1981; Hippodamia quinquesignata - Shull, 1948; Coleomegilla maculata - Hurst et al., 1996; Adonia variegata - Hurst et al., 1998a), and are suspected in several others (Majerus, 1994; Majerus \& Hurst, 1997).

Identification of the agents responsible for malekilling in several coccinellids has revealed malekilling to be caused by bacteria (in A. bipunctata, Rickettsia - Werren et al., 1994; Spiroplasma Hurst et al., 1998b; Wolbachia - G. D. D. Hurst et al., unpubl. data; in Coleomegilla maculata and

*Correspondence. E-mail: tmom@mole.bio.cam.ac.uk
Adonia variegata, Blattabacterium - Hurst et al., 1997a, 1998a).

Majerus \& Hurst (1997) have argued that coccinellids are a model system for the study of the evolution of male-killing endosymbionts and their consequences for their hosts. This argument is based on a knowledge of the advantages of male-killing in coccinellids: resource reallocation from male-killed embryos to sibling females (Hurst et al., 1992) and reduction in sibling cannibalism of infected female embryos (Majerus, 1994), and on the evolution of male-killing in several widely divergent bacterial symbionts of coccinellids.

Harmonia axyridis exhibits all the features that make it liable to invasion by male-killers (Majerus \& Hurst, 1997). Eggs are laid in batches. Neonate larvae consume unhatched eggs (Kawai, 1978; Ng, 1986; Osawa, 1989). This consumption has been shown to confer a significant survival advantage on 
neonates, particularly at low aphid density (Osawa, 1992). Furthermore, some female specimens of $H$. axyridis are known to produce highly female-biased progenic sex ratios (Matsuka et al., 1975), the female-bias trait is maternally inherited, although with varying levels of transmission efficiency (Matsuka et al., 1975), and the trait is antibiotic sensitive (Gotoh \& Niijima, 1986). It is probable that this coccinellid is infected with one or more male-killing bacteria (for review, see Hurst \& Majerus, 1993).

This paper describes studies on the prevalence of male-killing in three Asian populations of $H$. axyridis. Substantial variation in the prevalence of male-killers in these populations is reported. The effect of antibiotics on the trait, using tetracycline and chloramphenicol, is reassessed, and the possible effects of male-killing on the demography of these populations are discussed.

\section{Materials and methods}

Initial detection of the male-killer trait

Collections of $H$. axyridis were made at overwintering sites in a suburb of Sapporo City, Japan (Sapp stock), in spring 1994, in the Altai Mountains, Mongolia, in autumn 1994 (Altai stock) and at Novosibirsk, Russia, in autumn 1994 (Novo stock). These stocks were transferred to Cambridge. The sample sex ratio was obtained. Each individual was anaesthetized with $\mathrm{CO}_{2}$, and its sex was ascertained from the presence or absence of a male-specific pronounced notch in the ventral portion of the last segment of the abdomen. The ladybirds were kept as mixed-sex, single-population stocks in $9 \mathrm{~cm}$ Petri dishes and fed daily on pea aphids (Acyrthosiphon pisum). Mating pairs were removed to fresh Petri dishes when observed. Because the original Sapp and Altai stocks were female-biased, some males were returned to the stock dishes after mating. In this way, 94, 46 and 11 isofemale lines were created from the Sapp, Altai and Novo stocks, respectively. When clutches of eggs had been laid, the ladybirds were removed to fresh Petri dishes. The eggs were counted and, once they had hatched, the hatch-rates were recorded. Unhatched eggs were scored as either yellow, indicating no obvious sign of embryonic development, or grey, indicating that the embryos had developed but failed to emerge from the eggs.

All larvae from the Sapp and Novo crosses were reared to adulthood when aphid availability allowed. All larvae from Altai females in which the egg hatch-rate was lower than $75 \%$ were retained, fed on pea aphids daily and sexed on emergence as adults. However, because of a shortage of pea aphids, larvae from those females that produced a high egg hatch-rate $(>75 \%)$ were discarded except for one or two clutches that were reared to ensure that some males resulted.

\section{The inheritance of the male-killing trait}

To confirm our scoring of the male-killing trait, its inheritance was tested. Female progeny from 15 Sapp sex ratio lines (producing 26 crosses), 18 Sapp normal lines ( 22 crosses), the one Altai sex ratio line (three crosses) and eight normal Altai lines (10 crosses) were outcrossed to males from their own populations. These crosses were treated in the same way as the original crosses. As further crosses were produced from the progeny of these crosses and subsequent generations (up to $F_{5}$ ), egg hatch-rates and progenic sex ratios were recorded as a matter of course.

\section{Sensitivity to antibiotics}

Previous studies on heritable female-biased sex ratios in coccinellids have revealed the trait to be curable by treatment with antibiotics (Gotoh \& Niijima, 1986; Hurst et al., 1992) and associated with bacterial endosymbionts. To establish whether this was true of the male-killing trait in both Sapp and Altai samples of $H$. axyridis, infected and uninfected stocks from both populations were treated with tetracycline. In addition, infected and uninfected lines from Sapporo were tested with a second antibiotic, chloramphenicol.

Females from both infected and uninfected Sapp and Altai lines were mated, fed on pea aphids and allowed to oviposit. The egg hatch-rates and progenic sex ratios from these females were recorded. From each group (infected Sapp, uninfected Sapp, infected Altai, uninfected Altai), some females were then fed, for approximately $1 \mathrm{~h}$ per day, on a diet of pure golden syrup, over a period of 4 weeks. The rest were fed for the same period daily on a diet of golden syrup containing $10 \% \mathrm{w} / \mathrm{v}$ tetracycline. At other times, the females were fed on pea aphids. Four Sapp SR and four Sapp N lines fed for 4 weeks with golden syrup were subsequently fed on chloramphenicol in golden syrup for 4 weeks. The hatch-rates, the number of yellow eggs and grey eggs and the sex ratios from egg clutches laid subsequent to these treatments were recorded.

(c) The Genetical Society of Great Britain, Heredity, 81, 683-691. 


\section{Results}

Initial detection of the male-killer trait

The sex ratios (given throughout as the proportion of males) in the three samples were: Sapp 0.394 $(n=287) ; \quad$ Altai $0.442 \quad(n=197) ; \quad$ Novo 0.533 $(n=30)$. The female bias in the Sapporo population is highly significant $\left(\chi_{1}^{2}=12.97, P<0.001\right)$, but the sex ratios of the other samples are not significantly different from 1:1.

The egg hatch-rates and sex ratios produced by each of the Sapp and Altai isofemale lines are given in Tables 1 and 2, respectively. Summary data for the Novo lines are given in Table 3.

Sapp lines were divided into six classes on the basis of egg hatch-rates, sex ratio and the number of progeny produced as follows. Normal $(\mathrm{N})$ : $>5$ progeny in family and sex ratio consistent with $1: 1$; sex ratio (SR): $>5$ progeny, egg hatch-rate $<0.7$ and only female progeny; incomplete sex ratio (iSR): $>5$ progeny, egg hatch-rate $<0.7$, significantly female-biased sex ratio but with at least one male produced; high hatch-rate sex ratio (hhrSR): as for SR above, but egg hatch-rate $>0.7$; incompletely ascertained (?N/?SR): as for N/SR above, but $<6$ progeny produced (data not shown).

Using these criteria, 30 out of 94 Sapp lines were classed as SR, one as iSR (single male in 21 progeny), one as hhrSR (egg hatch-rate of 0.74 , producing 11 female progeny) and 10 as probably bearing a male-killer (?SR). If the families producing fewer than six progeny (?N/?SR) are excluded from the analysis, on the basis of incomplete ascertainment, the frequency of the sex ratio trait is 32 from 65 or $0.49(95 \%$ confidence interval for prevalence $=0.37-0.61)$.

Altai lines were split into three classes as follows. Normal $(\mathrm{N})$ : at least one male produced; probable normal (?N): no progeny resulting, but egg hatchrate $>0.7$; sex ratio (SR): egg hatch-rate $<0.7$ and only female progeny.

Only one of the 46 lines (2.2\%) was classed as SR, producing 21 females $(P=0.00000048)$.

None of the 11 Novo lines produced either low egg hatch-rates or a significantly female-biased sex ratio.

Analysis of the egg hatch-rates from the Sapp SR, iSR, hhrSR and $\mathrm{N}$ lines gave means of 0.418 from the three sex ratio classes combined, and 0.755 for the $\mathrm{N}$ lines. The mean egg hatch-rate from the Altai normal lines was 0.794 . The egg hatch-rate from the single Altai SR line was 0.49 , this line being one of only three of the 46 Altai lines in which less than half the eggs hatched.
Conclusion A strong female-biased sex ratio, associated with a low egg hatch-rate, was detected in females from both Sapp and Altai samples, but not from the Novo sample. The frequency of females bearing this trait was much greater in the Sapp sample than in the Altai sample $\left(\chi_{1}^{2}=27.98\right.$, $P<0.001)$. In the 32 lines from Sapp showing the trait (excluding the ?SR lines that only produced females), only a single male resulted from 714 progeny, indicating the vertical transmission efficiency of the trait to be very high (0.9986) in this population. The vertical transmission efficiency in the one Altai SR line was $100 \%(n=21)$.

\section{The inheritance of the male-killing trait}

The progeny of females from lines classified as potentially infected (16 lines, 29 crosses), including one of the Sapp ?SR lines, produced only daughters, whereas those from lines classified as normal (26 lines, 32 crosses), including five ?N, produced both sons and daughters in roughly equal numbers. Because of a lack of male progeny from lines classed as infected, we were unable to test whether surviving male progeny from infected females carried the trait (the only male produced from an infected line died shortly after eclosion and before mating).

All further crosses (numbering $74 \mathrm{SR}$ and $55 \mathrm{~N}$ families, up to $F_{5}$ ) produced progenic sex ratios consistent with the sex ratio status of their mother. The mean egg hatch-rates for the SR and $\mathrm{N}$ lines were 0.47 and 0.81 , respectively. The SR lines produced 963 female progeny with no males, confirming the high vertical transmission efficiency observed in the initially female-biased families.

Conclusion The criteria for recognizing females infected with the male-killing trait appear to be sound. The male-killing trait is maternally inherited with a vertical transmission efficiency in excess of 0.99 .

\section{Sensitivity to antibiotics}

The proportion of grey eggs, egg hatch-rates and sex ratios of progeny from clutches produced by these females, both before and after treatment with golden syrup, or with golden syrup and antibiotic, are given in Table 4.

None of the SR lines produced any males prior to antibiotic treatment. Treatment with golden syrup on its own had no effect on progenic egg hatch-rates $\left(\chi_{1}^{2}=1.81, P>0.05\right)$ or sex ratio. Treatment of SR females with tetracycline or chloramphenicol in 
686

T. M. O. MAJ ERUS ET AL.

Table 1 Egg hatch rates, progenic sex ratios and sex ratio status for families of Harmonia axyridis from Sapporo City, Japan

\begin{tabular}{|c|c|c|c|c|c|}
\hline Line & $\begin{array}{l}\text { No. of } \\
\text { eggs laid }\end{array}$ & $\begin{array}{c}\text { Egg } \\
\text { hatch-rate }\end{array}$ & $\begin{array}{l}\text { No. of } \\
\text { progeny }\end{array}$ & Sex ratio & $\begin{array}{l}\text { Sex ratio } \\
\text { class }\end{array}$ \\
\hline H1 & 163 & 0.43 & 22 & 0.00 & SR \\
\hline H3 & 159 & 0.26 & 7 & 0.00 & SR \\
\hline $\mathrm{H} 4$ & 73 & 0.88 & 26 & 0.50 & $\mathrm{~N}$ \\
\hline H5 & 56 & 0.38 & 21 & 0.05 & iSR \\
\hline H6 & 193 & 0.47 & 29 & 0.00 & SR \\
\hline H8 & 104 & 0.90 & 35 & 0.43 & $\mathrm{~N}$ \\
\hline H9 & 44 & 0.55 & 7 & 0.71 & $\mathrm{~N}$ \\
\hline H10 & 76 & 0.89 & 17 & 0.65 & $\mathrm{~N}$ \\
\hline H11 & 223 & 0.44 & 25 & 0.00 & SR \\
\hline $\mathrm{H} 12$ & 124 & 0.38 & 25 & 0.00 & SR \\
\hline H13 & 157 & 0.71 & 29 & 0.55 & $\mathrm{~N}$ \\
\hline H14 & 325 & 0.42 & 40 & 0.00 & SR \\
\hline H15 & 144 & 0.75 & 22 & 0.64 & $\mathrm{~N}$ \\
\hline H17 & 187 & 0.91 & 54 & 0.50 & $\mathrm{~N}$ \\
\hline H19 & 119 & 0.33 & 20 & 0.00 & SR \\
\hline $\mathrm{H} 21$ & 102 & 0.23 & 6 & 0.00 & SR \\
\hline $\mathrm{H} 22$ & 63 & 0.56 & 21 & 0.33 & $\mathrm{~N}$ \\
\hline $\mathrm{H} 25$ & 298 & 0.36 & 59 & 0.00 & SR \\
\hline $\mathrm{H} 26$ & 84 & 0.49 & 9 & 0.89 & $\mathrm{~N}$ \\
\hline $\mathrm{H} 27$ & 132 & 0.75 & 8 & 0.25 & $\mathrm{~N}$ \\
\hline $\mathrm{H} 29$ & 194 & 0.90 & 84 & 0.57 & $\mathrm{~N}$ \\
\hline H30 & 181 & 0.94 & 61 & 0.57 & $\mathrm{~N}$ \\
\hline f1 & 109 & 0.32 & 11 & 0.00 & SR \\
\hline f2 & 164 & 0.63 & 6 & 0.83 & $\mathrm{~N}$ \\
\hline $\mathrm{f} 4$ & 147 & 0.97 & 32 & 0.56 & $\mathrm{~N}$ \\
\hline f5 & 47 & 0.74 & 11 & 0.00 & hhrSR \\
\hline f6 & 142 & 0.39 & 14 & 0.00 & SR \\
\hline f7 & 203 & 0.47 & 47 & 0.00 & SR \\
\hline f8 & 156 & 0.38 & 22 & 0.00 & SR \\
\hline f11 & 399 & 0.42 & 52 & 0.00 & SR \\
\hline f12 & 185 & 0.40 & 26 & 0.00 & SR \\
\hline f13 & 203 & 0.50 & 47 & 0.00 & SR \\
\hline f14 & 275 & 0.36 & 32 & 0.00 & SR \\
\hline f16 & 141 & 0.64 & 35 & 0.00 & SR \\
\hline $\mathrm{f} 17$ & 203 & 0.40 & 8 & 0.00 & SR \\
\hline f18 & 201 & 0.54 & 32 & 0.00 & SR \\
\hline f19 & 148 & 0.70 & 21 & 0.38 & $\mathrm{~N}$ \\
\hline $\mathrm{f} 21$ & 82 & 0.73 & 20 & 0.55 & $\mathrm{~N}$ \\
\hline f22 & 107 & 0.83 & 6 & 0.83 & $\mathrm{~N}$ \\
\hline f24 & 170 & 0.36 & 31 & 0.00 & SR \\
\hline f26 & 111 & 0.48 & 7 & 0.00 & SR \\
\hline f27 & 202 & 0.71 & 21 & 0.38 & $\mathrm{~N}$ \\
\hline f30 & 66 & 0.42 & 11 & 0.00 & SR \\
\hline $\mathrm{f} 31$ & 110 & 0.32 & 12 & 0.00 & SR \\
\hline f33 & 83 & 0.49 & 6 & 0.67 & $\mathrm{~N}$ \\
\hline f34 & 131 & 0.78 & 26 & 0.46 & $\mathrm{~N}$ \\
\hline f37 & 73 & 0.96 & 19 & 0.42 & $\mathrm{~N}$ \\
\hline $\mathrm{f} 41$ & 227 & 0.70 & 13 & 0.38 & $\mathrm{~N}$ \\
\hline $\mathrm{f} 43$ & 80 & 0.76 & 14 & 0.43 & $\mathrm{~N}$ \\
\hline f 44 & 104 & 0.62 & 15 & 0.53 & $\mathrm{~N}$ \\
\hline $\mathrm{f} 45$ & 108 & 0.87 & 11 & 0.27 & $\mathrm{~N}$ \\
\hline
\end{tabular}

(c) The Genetical Society of Great Britain, Heredity, 81, 683-691. 
Table 1 Continued

\begin{tabular}{lccccc}
\hline Line & $\begin{array}{c}\text { No. of } \\
\text { eggs laid }\end{array}$ & $\begin{array}{c}\text { Egg } \\
\text { hatch-rate }\end{array}$ & $\begin{array}{c}\text { No. of } \\
\text { progeny }\end{array}$ & Sex ratio & $\begin{array}{c}\text { Sex ratio } \\
\text { class }\end{array}$ \\
\hline $\mathrm{f} 46$ & 51 & 0.43 & 8 & 0.00 & SR \\
$\mathrm{f} 50$ & 106 & 0.55 & 19 & 0.00 & SR \\
$\mathrm{f} 51$ & 71 & 0.34 & 9 & 0.00 & $\mathrm{SR}$ \\
$\mathrm{f} 53$ & 62 & 0.34 & 6 & 0.00 & $\mathrm{SR}$ \\
$\mathrm{f} 55$ & 80 & 0.88 & 8 & 0.38 & $\mathrm{~N}$ \\
$\mathrm{f} 58$ & 98 & 0.53 & 6 & 0.50 & $\mathrm{~N}$ \\
$\mathrm{f} 62$ & 34 & 0.94 & 15 & 0.60 & $\mathrm{~N}$ \\
$\mathrm{f} 63$ & 38 & 0.45 & 8 & 0.00 & $\mathrm{SR}$ \\
$\mathrm{f} 65$ & 65 & 0.80 & 8 & 0.63 & $\mathrm{~N}$ \\
$\mathrm{f67}$ & 54 & 0.44 & 10 & 0.00 & $\mathrm{SR}$ \\
$\mathrm{f} 69$ & 88 & 0.90 & 9 & 0.44 & $\mathrm{~N}$ \\
$\mathrm{f70}$ & 48 & 0.40 & 6 & 0.83 & $\mathrm{~N}$ \\
$\mathrm{f} 72$ & 66 & 0.79 & 10 & 0.50 & $\mathrm{~N}$ \\
$\mathrm{f} 78$ & 24 & 0.71 & 8 & 0.38 & $\mathrm{~N}$ \\
\hline
\end{tabular}

The sex ratio is given as the proportion of males in progeny. Sex ratio status classes are designated as described in the text.

golden syrup did not cause an increase in egg hatchrates (over all families, pretreatment hatch-rate $=$ 0.56 ; post-treatment hatch-rate $=0.44$ ). However, the proportion of eggs showing signs of embryonic development (hatching + grey eggs) did increase significantly in SR lines treated with antibiotics $\left(\chi_{1}^{2}=38.47, \quad P<0.001\right)$. This increase was not observed in the $\mathrm{N}$ lines treated with either antibiotic (for tetracycline $\chi_{1}^{2}=1.41, P>0.05$; for chloramphenicol $\chi_{1}^{2}=2.49, P>0.05$ ).

Four of the seven SR families treated with tetracycline and all four SR families treated with chloramphenicol produced at least one male after treatment. One of these families (A28) produced a sex ratio subsequent to antibiotic treatment that was no longer strongly female-biased.

Four post-tetracycline $F_{1}$ females of A28 were subsequently mated to unrelated males, each producing a normal sex ratio in their progeny (total of 71 males and 83 females), suggesting that, in this case, the cure effected was complete and heritable.

Conclusion Treatment with antibiotics produced a full heritable cure of the sex ratio trait in one line, with some alleviation of the symptoms in seven of the other 10 SR lines. Overall, egg hatch-rates in SR lines treated with antibiotics did not increase; however, the proportion of eggs that showed signs of embryonic development did increase, and some males were produced in eight of the 11 SR lines. It is concluded that the male-killers in both the Sapp and the Altai populations are probably bacteria.

\section{Discussion}

The analysis of sex ratios in $H$. axyridis from three populations from different geographical regions shows that some females in two of these produce only, or almost only, daughters. Observation of egg hatch-rates suggests that the bias in sex ratio in these females is the result of an early male-killer, similar to that reported in other coccinellids. Males are killed early in embryogenesis. The sex ratio trait is inherited maternally, again as are male-killers in other coccinellids, suggesting that the male-killer may be a cytoplasmic endosymbiont that has a very high vertical transmission efficiency. It is notable that in none of the original families or any of the subsequent crosses set up from them was there any substantial decrease in the sex ratio produced over time, indicating that the 'progressive SR' trait reported by Matsuka et al. (1975) was absent from our stocks.

Treatment with antibiotics failed to produce an increase in egg hatch-rates in SR lines, as has been observed in other studies on male-killers in coccinellids (Gotoh \& Niijima, 1986; Hurst et al., 1992, 1996). However, a significant increase in the proportion of eggs showing embryonic development was observed after antibiotic treatment, and 8 of the 11 SR females treated with antibiotics subsequently produced some male progeny. The small proportion of males produced after treatment, in all lines with the exception of A28, indicates that treatment with tetracycline or chloramphenicol does not usually 
effect a complete cure, contrary to previous reports (Gotoh \& Niijima, 1986; Hurst et al., 1992, 1996). A complete cure was produced in one only line (A28), the cure in this line being shown to be heritable.

Table 2 Egg hatch-rates, progenic sex ratios and sex ratio status for families of Harmonia axyridis from Altai Mountains, Mongolia

\begin{tabular}{|c|c|c|c|c|c|}
\hline Line & $\begin{array}{l}\text { No. of } \\
\text { eggs laid }\end{array}$ & $\begin{array}{c}\text { Egg } \\
\text { hatch-rate }\end{array}$ & $\begin{array}{l}\text { No. of } \\
\text { progeny }\end{array}$ & Sex ratio & $\begin{array}{l}\text { Sex ratio } \\
\text { class }\end{array}$ \\
\hline Alt1 & 93 & 0.92 & 5 & 0.6 & $\mathrm{~N}$ \\
\hline Alt2 & 28 & 0.89 & 2 & 0.5 & $\mathrm{~N}$ \\
\hline Alt3 & 72 & 0.90 & 8 & 0.5 & $\mathrm{~N}$ \\
\hline Alt3a & 141 & 0.86 & 0 & - & $? \mathrm{~N}$ \\
\hline Alt4 & 126 & 0.88 & 4 & 0.5 & $\mathrm{~N}$ \\
\hline Alt5 & 189 & 0.49 & 21 & 0 & SR \\
\hline Alt7 & 157 & 0.76 & 6 & 0.83 & $\mathrm{~N}$ \\
\hline Alt8 & 244 & 0.87 & 4 & 0.25 & $\mathrm{~N}$ \\
\hline Alt9 & 117 & 0.68 & 6 & 0.33 & $\mathrm{~N}$ \\
\hline Alt10 & 181 & 0.64 & 5 & 0.6 & $\mathrm{~N}$ \\
\hline Alt12 & 114 & 0.85 & 5 & 0.8 & $\mathrm{~N}$ \\
\hline Alt13 & 207 & 0.87 & 4 & 0.25 & $\mathrm{~N}$ \\
\hline Alt14 & 245 & 0.81 & 3 & 0.67 & $\mathrm{~N}$ \\
\hline Alt15 & 364 & 0.85 & 10 & 0.4 & $\mathrm{~N}$ \\
\hline Alt17 & 155 & 0.72 & 3 & 1 & $\mathrm{~N}$ \\
\hline Alt18 & 85 & 1.0 & 4 & 0.5 & $\mathrm{~N}$ \\
\hline Alt20 & 177 & 0.96 & 9 & 0.22 & $\mathrm{~N}$ \\
\hline Alt21 & 266 & 0.93 & 4 & 0.75 & $\mathrm{~N}$ \\
\hline Alt22 & 200 & 0.97 & 5 & 0.2 & $\mathrm{~N}$ \\
\hline Alt23 & 226 & 0.92 & 6 & 0.67 & $\mathrm{~N}$ \\
\hline Alt24 & 130 & 0.69 & 6 & 0.17 & $\mathrm{~N}$ \\
\hline Alt25 & 133 & 0.75 & 6 & 0.33 & $\mathrm{~N}$ \\
\hline Alt26 & 107 & 0.79 & 10 & 0.7 & $\mathrm{~N}$ \\
\hline Alt27 & 113 & 0.90 & 4 & 0.5 & $\mathrm{~N}$ \\
\hline Alt29 & 140 & 0.86 & 7 & 0.14 & $\mathrm{~N}$ \\
\hline Alt31 & 103 & 0.92 & 16 & 0.56 & $\mathrm{~N}$ \\
\hline Alt32 & 27 & 0.48 & 21 & 0.57 & $\mathrm{~N}$ \\
\hline Alt34 & 90 & 0.67 & 8 & 0.75 & $\mathrm{~N}$ \\
\hline Alt35 & 55 & 0.93 & 4 & 0.25 & $\mathrm{~N}$ \\
\hline Alt36 & 190 & 0.66 & 2 & 0.5 & $\mathrm{~N}$ \\
\hline Alt37 & 196 & 0.82 & 9 & 0.44 & $\mathrm{~N}$ \\
\hline Alt38 & 153 & 0.61 & 5 & 0.4 & $\mathrm{~N}$ \\
\hline Alt39 & 143 & 0.92 & 19 & 0.42 & $\mathrm{~N}$ \\
\hline Alt40 & 49 & 0.49 & 4 & 0.75 & $\mathrm{~N}$ \\
\hline Alt42 & 131 & 0.56 & 6 & 0.5 & $\mathrm{~N}$ \\
\hline Alt43 & 113 & 0.73 & 6 & 0.17 & $\mathrm{~N}$ \\
\hline Alt47 & 140 & 0.55 & 3 & 0.33 & $\mathrm{~N}$ \\
\hline Alt48 & 91 & 0.77 & 8 & 0.38 & $\mathrm{~N}$ \\
\hline Alt49 & 122 & 0.75 & 10 & 0.7 & $\mathrm{~N}$ \\
\hline Alt50 & 80 & 0.75 & 8 & 0.5 & $\mathrm{~N}$ \\
\hline Alt51 & 141 & 0.95 & 5 & 0.4 & $\mathrm{~N}$ \\
\hline Alt52 & 179 & 0.79 & 7 & 0.86 & $\mathrm{~N}$ \\
\hline Alt53 & 91 & 0.90 & 5 & 0.2 & $\mathrm{~N}$ \\
\hline Alt54 & 23 & 0.78 & 3 & 0.33 & $\mathrm{~N}$ \\
\hline Alt55 & 223 & 0.78 & 5 & 0.4 & $\mathrm{~N}$ \\
\hline Alt63 & 72 & 0.72 & 5 & 0.6 & $\mathrm{~N}$ \\
\hline
\end{tabular}

The sex ratio is given as the proportion of males in progeny. Three sex ratio classes are designated as described in the text. 
Table 3 Summary data for 11 families of Harmonia axyridis from Novosibirsk, Russia

\begin{tabular}{lccccc}
\hline $\begin{array}{l}\text { No. of } \\
\text { families }\end{array}$ & $\begin{array}{c}\text { No. of eggs } \\
\text { laid }\end{array}$ & $\begin{array}{c}\text { Mean egg } \\
\text { hatch-rate }\end{array}$ & $\begin{array}{c}\text { No. of } \\
\text { progeny }\end{array}$ & $\begin{array}{c}\text { Sex } \\
\text { ratio }\end{array}$ & $\begin{array}{c}\text { Sex ratio } \\
\text { class }\end{array}$ \\
\hline 11 & 1082 & 0.93 & 238 & 0.5 & All N \\
& $(28-217)$ & $(0.73-1)$ & $(14-35)$ & $(0.385-0.625)$ & \\
\hline
\end{tabular}

Data ranges are given in brackets. All families were diagnosed as normal with respect to sex ratio.

The prevalence of infection found varied between the three populations sampled. In the Sapp sample, the prevalence was almost $50 \%$, the highest prevalence of any male-killer reported in a coccinellid. In the Altai sample, only one female out of 46 produced a female-biased sex ratio. The prevalence in this population is thus likely to be less than $10 \%$. None of the females from Novo produced a biased sex ratio; however, the number of families involved was too small to say with confidence that the Novo population lacks male-killers. Despite this, the available data show that the prevalence of the male-killer in both the Altai Mountains and Novosibirsk populations is substantially lower than that occurring in Sapporo.

Two questions arise from these findings. First, what factors might cause differences in the prevalence of male-killers in different populations? Secondly, how do different male-killing prevalence levels influence population sex ratio and demography?

\section{Factors influencing the prevalence of male-killer infection}

Crucial to the prevalence of male-killers in a population will be the vertical transmission efficiency of the male-killer and the benefit accruing to female progeny of infected females as a result of the death of their male siblings (Hurst et al., 1997b).

The vertical transmission efficiency of the $H$. axyridis male-killer is very high under laboratory conditions. If this rate is representative of the vertical transmission efficiency in the wild, the rate of production of uninfected progeny, either male or female, from infected females in a population, will be very low.

The advantage that accrues to infected female offspring from the death of their male siblings will depend upon two main factors (Hurst et al., 1992): first, the reduction in their probability of being cannibalized by siblings (Majerus, 1994); and, secondly, the reduction in the probability that neonate larvae starve to death in the period immediately after dispersing from their egg clutch, while they are seeking and attempting to subdue their first aphid prey. The latter will depend upon the aphid density, the size of aphids, the defences of aphids and, possibly, the presence of alternative foods in the form of honey-dew or batches of conspecific coccinellid eggs that can be cannibalized.

Do the factors that influence male-killer infection levels vary in the different populations? Extensive field studies to collect data on vertical transmission efficiencies, egg and neonate larval size, egg clutch size, egg hatch synchroneity and available prey species size and population demography, from populations differing in their male-killer prevalence, will be needed to answer this question.

\section{The influence of male-killers on population demography}

The presence of male-killing endosymbionts can have effects on population sex ratios, biasing them significantly in favour of females. For example, the male-killing rickettsid that infects $7 \%$ of Adalia bipunctata females in Cambridge, England, is associated with a significantly female-biased population sex ratio (Hurst et al., 1993). In the case of the Sapp sample, the high level of the male-killer trait appears to have led to a significantly female-biased population sex ratio $(60.6 \%$ females, $n=287$; assuming that the sex ratio in the overwintering population is representative). If the Sapp population is at equilibrium, there must be strong overall selection for nuclear resistance genes to the male-killing behaviour of this endosymbiont. This selection will act primarily through males (Werren, 1987; Hurst, 1991). If, on the other hand, the Sapp male-killer is still increasing in frequency, this could ultimately have a significant effect on the population as the sex ratio becomes increasingly biased.

In most sexually reproducing animals, the sex ratio is maintained at, or close to, $1: 1$ by frequency- 
dependent selection (Fisher, 1930), and females are the limiting sex. In populations in which males are rare compared with females, it is possible that males become the limiting sex, with substantial evolutionary consequences for intersexual and intrasexual behaviour (Hamilton, 1967). Given the strong (and possibly increasing) female bias in the sex ratio in the Sapporo population of $H$. axyridis, coupled with reported temporally variable mating preferences by both females and males of this species (Osawa \& Nishida, 1992), it is possible that the reproductive behaviour of these ladybirds has been, and is, affected by selective factors different from those that affect populations with more equitable sex ratios.

Table 4 The effect of treatment with antibiotics on the sex ratio trait in Harmonia axyridis

\begin{tabular}{|c|c|c|c|c|c|c|c|c|}
\hline \multirow{2}{*}{$\begin{array}{l}\text { Line } \\
\text { and } \\
\text { treatment }\end{array}$} & \multicolumn{4}{|c|}{ Pretreatment } & \multicolumn{4}{|c|}{ Post-treatment } \\
\hline & $\begin{array}{l}\text { Proportion of } \\
\text { grey eggs }\end{array}$ & $\begin{array}{l}\text { Hatch- } \\
\text { rate }\end{array}$ & $\begin{array}{l}\text { No. of } \\
\text { progeny }\end{array}$ & $\begin{array}{l}\text { Sex } \\
\text { ratio }\end{array}$ & $\begin{array}{c}\text { Proportion of } \\
\text { grey eggs }\end{array}$ & $\begin{array}{l}\text { Hatch- } \\
\text { rate }\end{array}$ & $\begin{array}{l}\text { No. of } \\
\text { progeny }\end{array}$ & $\begin{array}{l}\text { Sex } \\
\text { ratio }\end{array}$ \\
\hline \multicolumn{9}{|l|}{ (a) } \\
\hline H31(Sapp) & 0.01 & 0.42 & 2 & 0 & 0.14 & 0.64 & 14 & 0 \\
\hline H46 (Sapp) & 0.02 & 0.53 & 14 & 0 & 0.21 & 0.62 & 18 & 0.06 \\
\hline H47 (Sapp) & 0.03 & 0.42 & 22 & 0 & 0.17 & 0.37 & 22 & 0 \\
\hline M11 (Altai) & 0.04 & 0.48 & 23 & 0 & 0.35 & 0.38 & 66 & 0.03 \\
\hline A28 (Altai) & 0.02 & 0.43 & 13 & 0 & 0.12 & 0.51 & 36 & 0.31 \\
\hline \multicolumn{9}{|l|}{ (b) } \\
\hline H56 (Sapp) & 0.00 & 0.48 & 35 & 0 & 0.03 & 0.41 & 30 & 0 \\
\hline M13 (Altai) & 0.07 & 0.41 & 9 & 0 & 0.04 & 0.53 & 16 & 0 \\
\hline A39 (Altai) & 0.11 & 0.32 & 21 & 0 & 0.01 & 0.39 & 11 & 0 \\
\hline A41 (Altai) & 0.04 & 0.51 & 16 & 0 & 0.09 & 0.41 & 28 & 0 \\
\hline \multicolumn{9}{|l|}{ (c) } \\
\hline H33 (Sapp) & 0.07 & 0.92 & 4 & 0.25 & 0.04 & 0.85 & 37 & 0.38 \\
\hline H35 (Sapp) & 0.01 & 0.92 & 31 & 0.48 & 0.03 & 0.88 & 27 & 0.52 \\
\hline H39 (Sapp) & 0.05 & 0.90 & 33 & 0.36 & 0.04 & 0.86 & 27 & 0.44 \\
\hline H55 (Sapp) & 0.04 & 0.88 & 28 & 0.57 & 0.02 & 0.94 & 20 & 0.50 \\
\hline H58 (Sapp) & 0.03 & 0.86 & 40 & 0.45 & 0.02 & 0.84 & 31 & 0.48 \\
\hline A38 (Altai) & 0.08 & 0.82 & 15 & 0.6 & 0.08 & 0.83 & 26 & 0.58 \\
\hline \multicolumn{9}{|l|}{ (e) } \\
\hline H33 (Sapp) & 0.06 & 0.90 & 41 & 0.37 & 0.04 & 0.88 & 14 & 0.57 \\
\hline H35 (Sapp) & 0.02 & 0.90 & 58 & 0.5 & 0.08 & 0.82 & 17 & 0.59 \\
\hline H55 (Sapp) & 0.03 & 0.91 & 48 & 0.54 & 0.05 & 0.89 & 22 & 0.5 \\
\hline H58 (Sapp) & 0.02 & 0.85 & 71 & 0.46 & 0.04 & 0.92 & 15 & 0.4 \\
\hline
\end{tabular}

Sex ratio lines were treated with a mixture of golden syrup and tetracycline (a), golden syrup alone (b) or golden syrup and chloramphenicol (d). Normal lines were treated with tetracycline in golden syrup (c) or chloramphenicol in golden syrup (e). The number of eggs that showed signs of development but failed to hatch (grey eggs), the egg hatch-rates and progenic sex ratios are given for before and after each treatment. 
Studies of the copulatory behaviour and mating preferences of the Sapporo population, in comparison with others that are less female-biased, should be enlightening.

\section{Acknow ledgements}

We wish to thank Alan Feast, Roger Day, Dennis Farrington and George Bennett for technical support. This work was carried out in a laboratory built with the support of the Wolfson Foundation. Gregory Hurst was funded via a Junior Research Fellowship from Christ's College.

\section{References}

FISHER, R. A. 1930. The Genetical Theory of Natural Selection. The Clarendon Press, Oxford.

GOTOH, T. AND NIIJIMA, к. 1986. Characteristics and agents of abnormal sex ratios (SR) in two aphidophagous coccinellid species. In: Hodek, I. (ed.) Ecology of the Aphidophaga, pp. 545-550. Academia, Prague.

HAmilton, w. D. 1967. Extraordinary sex ratios. Science, 156, 477-488.

HU, K. 1979. Maternally inherited 'sonless' abnormal sex ratio condition in the ladybeetle Harmonia axyridis. Acta Genet. Sin., 6, 296-304.

HURST, G. D. D. AND MAJERUS, M. E. N. 1993. Why do maternally inherited micro-organisms kill males? Heredity, 71, 81-95.

HURST, G. D. D., MAJERUS, M. E. N. AND WALKER, L. E. 1992. Cytoplasmic male killing elements in Adalia bipunctata (Linnaeus) (Coleoptera: Coccinellidae). Heredity, 69, 84-91.

HURST, G. D. D., MAJERUS, M. E. N. AND WALKER, L. E. 1993. The importance of cytoplasmic male killing elements in natural populations of the two spot ladybird, Adalia bipunctata (Linnaeus) (Coleoptera: Coccinellidae). Biol. J. Linn. Soc., 49, 195-202.

HURST, G. D. D., HAMMARTON, T., OBRYCKI, J. J., MAJERUS, T. M. O., WALKER, L. E., BERTRAND, D. AND MAJERUS, M. E. N. 1996. Male-killing in a fifth coccinellid beetle, Coleomegilla maculata. Heredity, 77, 177-185.

HURST, G. D. D., HAMMARTON, T. M., BANDI, C., MAJERUS, T. M. O., BERTRAND, D. AND MAJERUS, M. E. N. 1997a. The diversity of inherited parasites of insects: the malekilling agent of the ladybird beetle Coleomegilla maculata is a member of the Flavobacteria. Genet. Res., 70, $1-6$.

HURST, G. D. D., HURST, L. D. AND MAJERUS, M. E. N. 1997 b. Cytoplasmic sex-ratio distorters. In: O’Neill, S. L., Hoffmann, A. A. and Werren, J. H. (eds) Influential Passengers, pp. 125-154. Oxford University Press, Oxford.
HURST, G. D. D., BANDI, C., SACCHI, L., COCHRANE, A., BERTRAND, D., KARACA, I. AND MAJERUS, M. E. N. 1998a. Adonia variegata (Coleoptera: Coccinellidae) bears a maternally inherited Flavobacteria that kills males only. Parasitology, in press.

HURST, G. D. D., VON SCHULENBERG, J. H. G., MAJERUS, T. M. O., BERTRAND, D., ZAKHAROV, I. A., BAUNGAARD, J. ET $A L$. 1998b. Invasion of one insect species by two different male-killing bacteria. Insect Mol. Biol., in press.

HURST, L. D. 1991. The incidences and evolution of cytoplasmic male killers. Proc. R. Soc. B, 244, 91-99.

KAWAI, A. 1978. Sibling cannibalism in the first instar larvae of Harmonia axyridis Pallas (Coleoptera, Coccinellidae). Kontyû, 46, 14-19.

LUS, Y. Y. 1947. Some rules of reproduction in populations of Adalia bipunctata: non-male strains in populations. Dokl. Akad. Nauk SSSR, 57, 951-954.

MAJERUS, M. E. N. 1994. Ladybirds. New Naturalist Series no. 81. HarperCollins, London.

MAJERUS, M. E. N. AND HURST, G. D. D. 1997. Coccinellids as a model system for the study of male killing endosymbionts. Entomophaga, 42, 13-20.

MATSUKA, M., HASHI, H. AND OKADA, I. 1975. Abnormal sex ratio found in the lady beetle Harmonia axyridis Pallas (Coleoptera: Coccinellidae). Appl. Ent. Zool., 10, 84-89.

NG, S. M. 1986. Effects of first instar cannibalism on the first instar larvae of four species of aphidophagous Coccinellidae. In: Hodek, I. (ed.) Ecology of the Aphidophaga, pp. 69-75. Academia, Prague.

NIIJIMA, K. AND NAKAJIMA, K. 1981. Abnormal sex ratio in Menochilius sexmaculatus (Fabricius). Bull. Fac. Agric. Tamagawa Univ., 21, 59-67.

OSAWA, N. 1989. Sibling and non-sibling cannibalism by larvae of a lady beetle Harmonia axyridis Pallas (Coleoptera: Coccinellidae) in the field. Res. Pop. Ecol.., 31, 153-160.

OSAWA, N. 1992. Sibling cannibalism in the ladybird beetle Harmonia axyridis: fitness consequences for mother and offspring. Res. Pop. Ecol.., 34, 45-55.

OSAWA, N. AND NISHIDA, T. 1992. Seasonal variation in elytral colour polymorphism in Harmonia axyridis (the ladybird beetle): the role of non-random mating. Heredity, 69, 297-307.

SHULl, H. F. 1948. An all-female strain of lady beetles with reversions to normal sex ratio. Am. Nat., 82, 241-251.

WERREN, J. H. 1987. The coevolution of autosomal and cytoplasmic sex ratio factors. J. Theor. Biol., 124, 317-334.

WERREN, J. H., HURST, G. D. D., ZHANG, W., BREEUWER, J. A. J., STOUTHAMER, R. AND MAJERUS, M. E. N. 1994. Rickettsial related male-killing in the ladybird beetle (Adalia bipunctata). J. Bacteriol., 176, 388-394. 